\title{
PENGARUH MODEL PEMBELAJARAN STUDENT TEAMS ACHIEVEMENT DIVISION (STAD) TERHADAP AKTIVITAS BELAJAR MATEMATIKA
}

\section{THE EFFECT OF STUDENT TEAMS ACHIEVEMENT DIVISION (STAD) LEARNING MODELS ON MATHEMATIC LEARNING ACTIVITIES}

\author{
HAMNI FADLILAH NASUTION ${ }^{1}$, DESY ROMANISYAHNIAR ${ }^{2}$ \\ ${ }^{12}$ IAIN Padangsidempuan, JI.T. Rizal Nurdin No.Km 4, RW.5, Sihitang, \\ Padangsidimpuan Tenggara, Kota Padang Sidempuan \\ email: ${ }^{1}$ hamnifadlilahnasution@gmail.com , ${ }^{2}$ romanisyah_niar@gmail.com
}

\begin{abstract}
Abstrak
Tujuan dari penelitian ini adalah 1) untuk mengetahui ada pengaruh model pembelajaran kooperatif tipe STAD terhadap aktivitas belajar matematika siswa dalam pembelajaran persamaan garis lurus dikelas VIII SMP N 2 Sumberjo. Populasi dalam penelitian ini adalah seluruh kelas VII yang berjumlah 82 siswa. Sampel dalam penelitian ini sebanyak 31 orang sebagai kelas eksperimen. Instrumen yang digunakan untuk mengumpulkan data tentang aktivitas belajar siswa adalah dengan menggunakan instrumen berupa lembar observasi yang berbentuk daftar cek memuat indikator-indikator aktivitas belajar yang dilakukan siswa. teknik analisis data yang digunakan adalah, uji normalitas, uji homogenitas, uji hipotesis atau uji t. Berdasarkan hasil analisis data yang diperoleh dapat disimpulkan bahwa terdapat metode pembelajaran kooperatif tipe STAD terhadap komunikasi matematika siswa pada materi Persamaan Kuadrat, dilihat dari hasil perhitungan uji t yang ditunjukkan pada table diatas diperoleh nilai signifikan 0,000 yang berarti lebih kecil dari taraf signifikan yaitu 0,05 yang berarti terdapat perbedaan aktivitas belajar siswa matematika yang menggunakan model STAD yang signifikan antara prettes, maupun post-tes. Hasil Observasi aktivitas belajar siswa ditunjukkan dengan kategori aktif. sedangkan Respon siswa terhadap pembelajaran matematika menggunakan model pembelajaran kooperatif tipe STAD menunjukkan keseluruhan menyatakan Ya. Hal ini berarti siswa memberikan respon Ya terhadap pembelajaran matematika dengan metode pembelajaran kooperatif tipe STAD karena siswa lebih kreatif dan dapat beraktivitas dengan kelompok lainnya.
\end{abstract}

\section{Kata kunci : Pembelajaran Student Teams Achievement Division (STAD), Aktivitas Belajar}

\begin{abstract}
The objectives of this study were 1) to determine the effect of the STAD cooperative learning model on students' mathematics learning activities in learning straight line equations in class VIII SMP N 2 Sumberjo. The population in this study were all class VII students totaling 82 students. The sample in this study were 31 people as the experimental class. The instrument used to collect data about student learning activities was to use an instrument in the form of an observation sheet in the form of a checklist containing indicators of student learning activities. The data analysis technique used is normality test, homogeneity test, hypothesis test or t test. Based on the results of the data analysis obtained, it can be concluded that there is a STAD type of cooperative learning method for students' mathematics communication in the Quadratic Equation material, seen from the results of the t test calculation shown in the table above, a significant value of 0.000 is obtained which means it is smaller than the significant level of 0.05. which means that there are significant differences in student learning activities using the STAD model between the prettes and the post-test. The results of the observation of student learning activities are indicated by the active category. while the student response to mathematics learning using the cooperative learning model type STAD shows that the whole states Yes. This means that students respond Yes to learning mathematics with the STAD cooperative learning method because students are more creative and can do activities with other groups.
\end{abstract}

\section{Keywords: Learning Student Teams Achievement Division (STAD), Learning Activities}




\section{Pendahuluan}

Pembelajaran matematika adalah salah satu bidang ilmu yang memegang peranan sangat penting dalam kehidupan sehari-hari. Berbagai permasalahan dalam kehidupan dapat dipecahkan dengan menggunakan konsep-konsep matematika. Selain itu, banyak bidang ilmu yang sangat memerlukan matematika untuk perkembangannya. Matematika itu bukan pengetahuan yang menyendiri dan dapat sempurna karena dirinya sendiri, tetapi keberadaannya itu untuk membantu manusia dalam memahami dan menguasai permasalahan sosial, ekonomi, dan alam[1].

Peranan matematika sangat penting dalam kehidupan dan pengembangan pengetahuan. Mengingat hal tersebut, sudah seharusnya konsep-konsep yang ada dalam matematika dapat dipelajari dengan baik oleh siswa. Namun, pada kenyataannya tidak sesuai dengan harapan tersebut. Pada umumnya, pelajaran matematika merupakan mata pelajaran yang tidak disenangi. Hal tersebut dapat menyebabkan rendahnya minat belajar matematika siswa.

Salah satu upaya yang dapat dilakukan untuk meningkatkan sumber daya manusia adalah peningkatan mutu pendidikan, baik prestasi belajar siswa maupun kemampuan guru dalam melaksanakan proses pembelajaran. Peningkatan mutu pendidikan diarahkan untuk meningkatkan kualitas manusia seutuhnya melalui olah hati, olah rasa, dan ulah raga agar memiliki daya saing dalam menghadapi tantangan global[2]. Banyak faktor yang menyebabkan minat belajar matematika rendah, dintaranya adalah rendahnya motivasi berprestasi siswa, tingkatan kognitif siswa, serta apresiasi siswa terhadap matematika. Hal serupa juga terjadi di SMP Negeri 2 Sumberjo.

Berdasarkan kenyataan di atas, masalah yang sangat menonjol yang dihadapi oleh pendidikan matematika adalah pada umumnya hasil belajar para siswa yang belum memuaskan. Hal itu disebabkan karena selama ini proses pembelajaran matematika yang ditemui masih secara konvensional seperti ekspositori, drill, atau bahkan ceramah. Proses ini hanya menekankan pada penyampaian tekstual semata dari pada mengembangkan kemampuan belajar dan membangun individu, sehingga sering kali dijumpai kecenderungan siswa yang kurang berminat untuk belajar. Akibatnya siswa lebih banyak pasif dan kurang terlibat dalam proses belajar mengajar. Kondisi seperti ini tidak akan menumbuh kembangkan aspek kemampuan dan aktivitas siswa seperti yang diharapkan. Menurut Eggen dan Kau chak bahwa siswa belajar secara efektif bila siswa secara aktif terlibat dalam pengorganisasian dan penemuan pertalian- pertalian (relationships) dalam informasi yang dihadapi. Aktivitas siswa ini menghasilkan kemampuan belajar dan peningkatan kemampuan pengetahuan serta pengembangan ketrampilan berpikir (thinking skills)[3].

Matematika dapat mengantar manusia berpikir dengan jelas dan logis. Matematika juga sebagai sarana untuk memecahkan masalah kehidupan seharihari, sarana pengembangan kreativitas dan sarana untuk meningkatkan kesadaran terhadap perkembangan kebudayaan. Selain itu juga, matematika mempunyai peranan sangat penting dalam menunjang keberhasilan pembangunan dibidang pendidikan karena bagi peserta didik penguasaan matematika akan menjadi sarana yang ampuh untuk mempelajari mata pelajaran yang lain[4].

Masalah lain yang cukup sulit dirasakan guru matematika adalah bagaimana bahan pelajaran dapat dikuasai oleh anak secara tuntas. Siswa memiliki perbedaan satu sama lainnya. Siswa berbeda dalam hal minat, kemampuan, kesenangan, pengalaman, dan cara belajar. Oleh karena itu kegiatan pembelajaran, organisasi kelas, materi pembelajaran, waktu belajar, alat belajar, dan cara penilaian perlu beragam sesuai karakteristik siswa. Menciptakan kegiatan belajar yang inovatif dan akan menempatkan guru sebagai fasilitator, mediator, penilai dan pengarah pembelajaran. Dalam melaksanakan fungsi tersebut guru harus memiliki kreativitas dan inovasi dalam merencanakan serta melakukan pembelajaran, sehingga kedua dimensi sains bisa muncul dalam kegiatan belajar.

Pada kenyataanya aktivitas siswa cendrung menurun. Dengan jumlah jam yang terbatas sulit sekali bagi guru untuk mengaktifkan siswa dalam kegiatan tertentu. Bila hal itu terjadi, siswa yang ditunjuk oleh guru saja yang aktif dan yang tidak ditunjuk akan pasif. Pembelajaran yang seperti ini menyebabkan aktivitas siswa tidak berkembang maksimal. Juga karena masing-masing siswa memiliki kemampuan yang berbeda dalam hal memahami materi pelajaran.

Aktivitas belajar dalam pembelajaran akan menghasilkan pengalaman untuk siswa. Pembelajaran berdasarkan pengalaman memiliki 3 asumsi : 1) Anda akan belajar paling baik jika anda secara pribadi 
terlibat dalam pengalaman belajar itu; 2) Pengetahuan harus ditemukan oleh anda sendiri; 3) komitmen terhadap pembelajaran akan tinggi apabila anda bebas menetapkan tujuan pembelajaran[5].

Pada prinsipnya belajar adalah berbuat, berbuat untuk mengubah tingkah laku, jadi melakukan kegiatan. Tidak ada belajar kalau tidak ada aktivitas. Maka aktivitas merupakan prinsif atau asas yang sangat penting di dalam interaksi belajarmengajar. Oleh karena itu, dibutuhkan model belajar yang tepat untuk menciptakan siswa aktif, karena selama ini sering sekali pada proses belajar model yang diterapkan adalah model konvensional. Aktivitas belajar dapat diciptakan dengan melaksanakan pembelajaran yang menyenangkan dengan menyajikan variasi model pembelajaran yang lebih memicu kegiatan siswa. Dengan demikian siswa akan lebih aktif dalam kegiatan pembelajaran[6].

Berdasarkan hasil observasi awal peneliti di SMP Negeri $2 \mathrm{Na}$. IX-X Sumberjo dengan melakukan wawancara terhadap guru mata pelajaran matematika yaitu Ibu Zubaidah, S.Pd tentang matematika dengan materi persamaan garis lurus, dapat dikatakan bahwa aktivitas belajar matematika dipengaruhi oleh berbagai faktor seperti: interaksi yang terjadi di dalam kelas, model pembelajaran dan media pembelajaran yang digunakan guru, sarana dan prasarana yang tersedia, kemampuan siswa dan sebagainya. Dalam suatu proses belajar mengajar, model pembelajaran yang diterapkan guru sangat berpengaruh terhadap aktivitas dan hasil belajar siswa. Jika model pembelajaran yang diterapkan guru tepat sesuai situasi dan kondisi maka hasil belajar akan tercapai secara maksimal. Aktivitas siswa dalam pelajaran Matematika memberikan gambaran tentang proses belajar belajarnya siswa tentang Matematika. Semakin banyak siswa melakukan aktivitas dalam proses belajar berarti kualitas penguasaan materi tentang suatu bahan ajar dapat terpenuhi sehingga otomatis hasil belajar siswa tercapai seoptimal mungkin.

Berdasarkan uraian tersebut, proses pembelajaran seyogyanya dipersiapkan dengan matang sehingga akan lebih efektif dan efisien yang tentunya akan berpengaruh pada aktivitas siswa. Pembelajaran mengandung arti adanya kegiatan pendidikan dan pembelajaran[7]. Pendidik juga memiliki peranan penting untuk memfasilitasi, membimbing dan membangkitkan aktivitas pada siswa sehingga menumbuhkan kecintaan untuk terus belajar khususnya mempelajari matematika. Model pembelajaran Kooperatif Tipe STAD mampu memenuhi apa yang dibutuhkan siswa selama pendidik selalu berupaya untuk merancang pembelajaran yang bermakna agar dapat meningkatkan aktivitas siswa dan dapat meningkatkan hasil belajar matematika siswa.

Model pembelajaran kooperatif tipe STAD (Student Teams Achievement Division) merupakan model pembelajaran yang melibatkan siswa untuk saling membantu dan mendukung dalam menyelesaikan tugas sehingga mempunyai banyak kesempatan untuk mengolah informasi dan meningkatkan keterampilan berkomunikasi. Model pembelajaran STAD (Student Teams-Achievement Divisions) merupakan salah satu model pembelajaran kooperatif untuk membangun pembelajaran yang aktif[8].

\section{Metode Penelitian}

Penelitian ini menggunakan jenis penelitian Kuantitatif dengan metode yang digunakan yaitu metode kuasi eksperimen dan desain penelitian yang digunakan yaitu Control Group Pre-test and Posttest Design. Rancangan ini melibatkan kelompok eksperimen dan kelompok kontrol.Sebelum diberikan perlakuan pada kedua kelas, maka terlebih dahulu diberikan pre-test. Selanjutnya kelompok eksperimen diberikan perlakuan dengan menggunakan model pembelajaran kooperatif tife STAD sedangkan kelompok kontrol diberikan pembelajaran menggunakan Pendekatan Konvensional, sampel dalam penelitian ini kelas VII SMP Negeri 2 Sumberjo dengan jumlah siswa 31 siswa. Instrumen yang digunakan untuk mengumpulkan data tentang aktivitas belajar siswa adalah dengan menggunakan instrumen berupa lembar observasi yang berbentuk daftar cek memuat indikator-indikator aktivitas belajar yang dilakukan siswa.

\section{Hasil Penelitian dan Pembahasan}

Data dalam penelitian ini memuat data kuantitaf yang diperoleh dari tes kemampuan yang observasi aktivitas belajar matematika siswa dan kulitatif diperoleh dari angket. Instrumen penelitian yang digunakan adalah aktivitas belajar matematika siswa yang terdiri dari 4 soal berbentuk uraian. Tes ini akan diuji cobakan oleh siswa sebelum pembelajaran tentang persamaan garis lurus. 
Hal : $48-54$

Hasil Pret-tes siswa seperti tabel berikut ini:

Tabel.1. Deskripsi Statistik Skor Pret-tes Kelas Eksperiment

\begin{tabular}{|c|c|c|}
\hline \multirow{2}{*}{ No } & \multirow{2}{*}{ Interval Nilai } & Frekuensi \\
\cline { 3 - 3 } & $40-44$ & Eksperimen \\
\hline 1 & $45-49$ & 4 \\
\hline 2 & $50-54$ & 5 \\
\hline 3 & $55-59$ & 3 \\
\hline 4 & $60-64$ & 1 \\
\hline 5 & $65-70$ & 6 \\
\hline 6 & Nilai Tertinggi & 12 \\
\hline \multicolumn{2}{|c|}{ Nilai Terendah } & 70 \\
\hline \multicolumn{2}{|c|}{ Mean ( rataan ) } & 40 \\
\hline \multicolumn{2}{|c|}{ Standar Deviasi } & 57,19 \\
\hline
\end{tabular}

Berdasarkan tabel1 diperoleh bahwa standart deviasi kelompok eksperimen adalah 10,616, rata-ratanya 57,19 dengan nilai terendah 40 dan nilai tertinggi 70 .

\section{Analisis Hasil Terhadap Post-tes}

Instrumen penelitian yang digunakan adalah tes aktivitas belajar matematika siswa yang terdiri dari 4 soal berbentuk uraian. Tes ini akan diuji cobakan oleh siswa sebelum pembelajaran tentang pokok bahasan simpangan rata-rata. Hasil post-test siswa seperti tabel berikut ini :

Tabel 2. Deskripsi Statistik Skor Post-tes Kelas Eksperimen

\begin{tabular}{|l|c|c|}
\hline No & Interval Nilai & Frekuensi \\
\cline { 3 - 3 } & & Eksperimen \\
\hline 1 & $40-44$ & 5 \\
\hline 2 & $45-49$ & 8 \\
\hline 3 & $50-54$ & 1 \\
\hline 4 & $55-59$ & 3 \\
\hline 5 & $60-64$ & 4 \\
\hline 6 & $65-70$ & 10 \\
\hline \multicolumn{2}{|c|}{ Nilai Tertinggi } & 57 \\
\hline \multicolumn{2}{|c|}{ Nilai Terendah } & 15 \\
\hline Mean ( rataan ) & 37,32 \\
\hline Standar Deviasi & 14.148 \\
\hline
\end{tabular}

Berdasarkan hasil analisis data aktivitas belajar siswa pada pertemuan I dan pertemuan II maka dapat disajikan hasil analisis seperti diuraikan dalam Tabel di bawah ini.

Tabel 3. Hasil Lembar Observasi

\begin{tabular}{|c|c|c|c|}
\hline No & $\begin{array}{c}\text { Pertemuan } \\
\text { ke- }\end{array}$ & $\begin{array}{c}\text { Rata-rata Skor Aktivitas } \\
\text { Belajar Siswa }(\bar{A}) .\end{array}$ & Kategori \\
\hline 1 & 1 & 14,57 & Aktif \\
\hline
\end{tabular}

Dalam menganalisis respon siswa digunakan skala Gruttman. Jawaban setiap item instrumen yang menggunakan skala Grutman mempunyai gradasi Ya dan Tidak.

Tabel 4. Skala Gruttman

\begin{tabular}{|c|c|}
\hline Item Jawaban & Skor \\
\hline Ya & 1 \\
\hline Tidak & 0 \\
\hline
\end{tabular}


Hal : $48-54$

Angket berisi pernyataan-pernyataan yang berkaitan dengan respon siswa terhadap pembelajaran matematika menggunakan model STAD. Hasil rekapitulasi Aktivitas Belajar Matematika siswa dapat dilihat pada tabel berikut:

Tabel 5. Hasil Angket Aktivitas Belajar Matematika Siswa

\begin{tabular}{|c|l|c|c|c|c|}
\hline No & \multicolumn{1}{|c|}{ Pernyataan } & \multicolumn{1}{|c|}{ Skor } & Ket \\
\cline { 2 - 5 } & Ya & Tidak & & \\
\hline 1 & $\begin{array}{l}\text { Apakah kamu mendengarkan bila guru } \\
\text { sedang menerangkan materi tersebut }\end{array}$ & 28 & 3 & 31 & Ya \\
\hline 2 & $\begin{array}{l}\text { Apakah kamu bersemangat untuk } \\
\text { mengikuti pelajaran matematika }\end{array}$ & 30 & 1 & 31 & Ya \\
\hline 3 & $\begin{array}{l}\text { Apakah kamu akan mengemukakan } \\
\text { pemikiran bila tidak diminta oleh guru }\end{array}$ & 25 & 6 & 31 & Ya \\
\hline 4 & $\begin{array}{l}\text { Apakah kamu merasa bosan ketika guru } \\
\text { menerangkan pelajaran melalui presentasi } \\
\text { kelompok }\end{array}$ & 1 & 30 & 31 & Tidak \\
\hline 5 & $\begin{array}{l}\text { Apakah kamu malas bila menerangkan materi } \\
\text { dengan menggunakan gambar }\end{array}$ & 29 & 2 & 31 & Tidak \\
\hline 6 & $\begin{array}{l}\text { Apakah kamu mau bila ditunjuk } \\
\text { membaca keputusan dalam kelompok }\end{array}$ & 25 & 6 & 31 & Ya \\
\hline 7 & $\begin{array}{l}\text { Apakah kamu membaca materi pelajaran } \\
\text { terlebih dahulu sebelum pelajaran dimulai }\end{array}$ & 17 & 14 & 31 & Ya \\
\hline 8 & $\begin{array}{l}\text { Apakah kamu akan mencatat bila } \\
\text { diminta guru }\end{array}$ & 21 & 10 & 31 & Ya \\
\hline 9 & $\begin{array}{l}\text { Apakah kamu sangat antusias saat } \\
\text { mendengarkan perdebatan tentang masalah } \\
\text { pelajaran }\end{array}$ & 18 & 13 & 31 & Ya \\
\hline 10 & $\begin{array}{l}\text { Apakah kamu tetap diam walaupun kamu } \\
\text { kurang mengerti materi yang diterangkan } \\
\text { guru }\end{array}$ & 15 & 16 & 31 & Tidak \\
\hline
\end{tabular}

Setelah data hasil penelitian di dapat, maka data akan dianalisis. Sebelum melakukan analisis, terlebih dahulu dilakukan pengujian prasyarat analisis data, yaitu uji normalitas dan uji homogenitas guna mengetahui apakah data yang diperoleh terdistribusi normal dan mempunyai ragam yang homogen atau tidak. Adapun hasil yang di dapat setelah dilakukan pengujian prasyaratan analisis data adalah sebagai berikut:

Tabel 6. Hasil Uji Normalitas Prettest dan Posttest pada Kelas Eksperimen

\begin{tabular}{|l|l|l|}
\hline \multirow{2}{*}{ Uji Normalitas } & Eksperimen \\
\cline { 2 - 3 } & Prettest & Posttest \\
\hline Sig. ( 2 - tailed) & 0,200 & 0,064 \\
\hline Kriteri & Sig. $>0,05$ & Sig. $>0,05$ \\
\hline Kesimpulan & Ho diterima & Ho diterima \\
\hline
\end{tabular}

Berdasarkan tabel 6 terlihat bahwa keempat data tersebut berdistribusi normal.

Tabel 7. Rekapitulasi Hasil Uji Homogenitas Pada Kelas Eksperimen

\begin{tabular}{|c|c|c|}
\hline Statistik & Prettest & Posttest \\
\hline Sig. & 0,551 & 0,438 \\
\hline UjiLevene's & Sig. $>0,05$ & Sig. $>0,05$ \\
\hline Kesimpulan & Homogen & Homogen \\
\hline
\end{tabular}

Berdasarkan tabel 7, terlihat bahwa kedua kelas tersebut memiliki varians yang homogen. 
Hal : $48-54$

\section{Pengujian Hipotesis}

Setelah dilakukan pengujian analisis, maka selanjutnya dilakukan pengujian hipotesis.Pengujian hipotesis dilakukan dengan statistic parametrick karena data kelas eksperimen dan kelas control berdistribusi normal dan homogen. Untuk mengetahui ada tidaknya perbedaan aktivitas belajar siswa pada kelas eksperimen dan kelas control digunakan pengujian hipotesis komparatif dua sampel independen (ujit independent sample test). Berikut adalah tabel hasil uji hipotesis data pretest dan posttest menggunakan uji $t$ independent sample test.

Tabel 8. Hasil Uji Hipotesis Data Prettest dan Posttest Kelas Eksperimen

\begin{tabular}{|c|c|c|}
\hline $\begin{array}{c}\text { Uji Hipotesis } \\
\text { IndependentSample } \\
\text { Test }\end{array}$ & Prettest & Posttest \\
\hline Sig. ( 2 - tailed) & 0,715 & 0,000 \\
\hline Kriteria & Sig. $>0,05$ & Sig. $<0,05$ \\
\hline Kesimpulan & $\mathrm{H}_{0}$ diterima & $\mathrm{H}_{\mathrm{a}}$ diterima \\
\hline
\end{tabular}

Berdasarkan tabel 8 terlihat bahwa untuk data prettest diperoleh nilai Sig.(1-tailed) sebesar 0,715. Nilai Sig. (1-tailed) $>0,05$ artinya hasil uji $t$ Independent Sample Test kelas eksperimen dinyatakan tidak terdapat perbedaan. Untuk data posttest diperoleh nilai Sig.(1-tailed) sebesar 0,000. Nilai Sig. (1tailed) $<0,05$ artinya hasil uji $t$ Independent Sample Test kelas eksperimen dinyatakan terdapat perbedaan. Jadi dapat disimpulkan bahwa terdapat pengaruh model pembelajaran kooperatif tipe STAD terhadap aktivitas belajar matematika siswa.

Dari hasil analisis data diatas diperoleh bahwa pengaruh model pembelajaran kooperatif tipe STAD terhadap aktivitas belajar matematika siswa adala perhitungan uji t yang ditunjukkan pada tabel diatas diperoleh nilai signifikan 0,000 yang berarti lebih kecil dari taraf signifikan yaitu 0,05 yang berarti terdapat perbedaan aktivitas belajar matematika yang menggunakan model stad yang signifikan antara pre-test maupun post-test.

Berdasarkan hasil analisis data aktivitas belajar siswa diperoleh skor rata-rata sebesar 14,01 dengan katagori aktif, dan ini telah memenuhi persyaratan pembelajaran dikatakan optimal. Dari angket siswa terhadap aktivitas belajar matematika siswa menunjukkan keseluruhan menyatakan ya. Hal ini berarti siswa memberikan respon ya terhadap aktivitas belajar matematika siswa karena siswa lebih kreatif dan dapat berkomunikasi dengan kelompok lainnya.

Berdasarkan hasil pengujian hipotesis dengan uji $t$ Independent Sample Test untuk sampel yang berdistribusi normal dan homogen diperoleh nilai Sig. (1-tailed) sebesar 0,000 dan nilai Sig. (1-tailed) $<0,05$ maka $\mathrm{H}_{0}$ ditolak dan $\mathrm{H}_{\mathrm{a}}$ diterima dengan kata lain rata-rata kemampuan aktivitas belajar matematika siswa pada kelompok eksperimen lebih tinggi.

\section{Kesimpulan}

Berdasarkan hasil uji hipotesis yang dilakukan, maka disimpulkan bahwa:

1. Berdasarkan hasil analisis data yang diperoleh dapat disimpulkan bahwa terdapat metode pembelajaran kooperatif tipe STAD terhadap komunikasi matematika siswa pada materi Persamaan Kuadrat, dilihat dari hasil perhitungan uji t yang ditunjukkan pada table diatas diperoleh nilai signifikan 0,000 yang berarti lebih kecil dari taraf signifikan yaitu 0,05 yang berarti terdapat perbedaan aktivitas belajar siswa matematika yang menggunakan model STAD yang signifikan antara prettes, maupun post-tes

2. Observasi aktivitas belajar siswa ditunjukkan dengan kategori "aktif".

3. Respon siswa terhadap pembelajaran matematika menggunakan model pembelajaran kooperatif tipe STAD menunjukkan keseluruhan menyatakan Ya. Hal ini berarti siswa memberikan respon $\mathrm{Ya}$ terhadap pembelajaran matematika dengan metode pembelajaran kooperatif tipe STAD karena siswa lebih kreatif dan dapat beraktivitas dengan kelompok lainnya 
Hal : $48-54$

\section{Daftar Pustaka}

[1] Budiani, Ni Luh. 2016. Penerapan Model Pembelajaran Kooperatif Tipe Jigsaw Untuk Meningkatkan Aktivitas Dan Hasil Belajar Siswa Kelas XI APA di SMK Negeri 1 Singaraja Tahun Ajaran 2015/2016. Skripsi (tidak diterbitkan). Undiksha Singaraja

[2] Siregar, S.U. 2016. Perbedaan Kemampuan Pemecahan Masalah Matematika Menurut Teori Belajar Bruner dan Teori Belajar Vigosky pada Kompetensi Dasar Menghitung Luas dan Keliling Bangun Datar kelas V Semester 2 SD Negeri 114375 Binaraga Rantauprapat. Jurnal Pembelajaran dan Matematika Sigma (JPMS). Vol. 2 No.2, hlm. 51-53. (2016)

[3] Marfana, Erwin, 2007. Perbedaan Persepsi Etika Penyusunan Laporan Keuangan dan Manajemen Laba Terhadap Mahasiswa Akuntansi dan Non Akuntansi.Skripsi S-1, Universitas Budi Luhur, Jakarta.

[4] Hrp, NA. 2017. Peningkatan Kemampuan Representasi Matematis dan Motivasi Belajar Siswa Melalui Model Pembelajaran Berbasis Proyek (Project Based Learning) di Kelas VII SMP Negeri 1 Torgamba Tahun Pelajaran 2016/2017. Jurnal Pembelajaran dan Matematika Sigma (JPMS). Vol. 3 No.1, hlm. 38-47 (2017)

[5] Harahap, MAM.,Harahap, NA., Irmayanti. 2019. Pengaruh Media Audio Visual terhadap Kemampuan Pemahaman Konsep. Jurnal Jomas. Vol. 1 No. 1 (2019)

[6] Yamin,M. 2007. Kiat Membelajarkan Siswa. Jakarta: Gaung Persada Press dan Center for Learning Innovation (CLI)

[7] Anggriyani, I., Hrp, NA. 2021. Peningkatan Daya Ingat Siswa terhadap Pembelajaran Matematika dengan Penggunaan Teknik Mnemonic pada Kelas XI MAS Al-Barakah. Jurnal Pembelajaran Matematika Inovatif. Vol. 4 No. 3 (2021)

[8] Suryani. 2019. Pengaruh Model Pembelajaran Student Teams Achievement Division (STAD) terhadap Kemampuan Pemecahan Masalah Matematika. Jurnal Pembelajaran dan Matematika Sigma (JPMS). Vol. 5, No. 1 (2019) hal.1-6 